\title{
Tourism special edition
}

Given that Brazil will be hosting the 2014 World Cup and the Olympic Games in 2016, this is a particularly appropriate moment for stimulating the robust and sustainable development of tourism in the country.

These events have placed our country under the spotlight and present an enormous range of opportunities and challenges for public and private managers. In this context, Ebape/FGV and IAG/PUC-Rio, held the Tourism in Rio de Janeiro International Seminar in March this year, with the participation of prominent Brazilian and foreign researchers and Brazilian tourism industry managers.

The seminar was held under the auspices of the project entitled Innovation Processes in Strategic Networks in the Tourism Sector: Levering Socio-Economic Development in the City of Rio de Janeiro (Pronex - n E$26 / 170.010 / 2008$ ), which is being developed jointly by the two universities with financial support from Faperj (The State of Rio de Janeiro Research Funding Foundation)

The discussions regarding the challenges and opportunities for the development of tourism in Brazil, which took place during the Tourism in Rio de Janeiro International Seminar, resulted in the production of several academic papers, eight of which were selected for inclusion in this special edition of $R A P$.

The articles encompass three thematic axes that are fundamental for conceptualizing the sustainable development of tourism in Brazil: strategy, innovation and education.

Strategic planning is discussed in this edition's first article, 'A model of destination competitiveness/sustainability: Brazilian perspectives,' in which the authors present their classic model for analyzing a tourist destination's competitiveness, as well as the results of their analysis of the Brazilian case.

The article 'Competitiveness of tourist destination' discusses the concept of competitiveness from a multidimensional viewpoint, using the theoretical framework developed in the scope of the study Competitiveness of the 65 Destinations Inducers of Regional Tourism Development, carried out by Getulio Vargas Foundation (FGV), in cooperation with the Brazilian Ministry of Tourism and Sebrae (Brazilian Micro and Small Enterprise Support Service). 
A strategic approach is also adopted by the article Evaluation of Collaborative Strategies for Ecotourism and Recreational Activities in Natural Parks of Rio de Janeiro, which presents an analysis of the implementation of collaborative strategies for the development of eco-tourism activities in national parks located in Rio de Janeiro.

Current Trends in the Global Tourism Industry: Evidence from the United States, analyzes tourism from a US perspective, offering insights for the formulation of strategies and public policies for the sector. As one of the tourism industry's most dynamic countries, in both generator and receiver terms, the United States constitutes an important benchmark for Brazil.

The importance of innovation for the tourism industry is discussed in the article entitled 'Innovative technological capability in firms of the tourism sector: a study of the hotels in the city of Rio de Janeiro during the 1990-2008 period,' which investigates innovation processes in tourism sector industries, and also in 'Innovation for sustainable urban tourism: some thoughts on best practice,' which addresses the issue of sustainable urban tourism, presenting the case of strategic measures taken by Australia's government to develop networks involving local tourist destinations

The need to strengthen the field of studies of tourism for the development of destinations permeates the article 'Higher education of tourism in Spain and its adaptation to the European higher education area,' which analyzes the changes that have occurred in tourism's educational system over the past few decades, especially in the case of Europe.

The article 'Scientific research in tourism: review of the literature from 2005 to 2009' presents the results of a bibliographical survey of 1,648 articles that were classified into macro-lines of research, indicating the themes that have been the subject of a greater number of investigations in the tourism area. Special emphasis is given to the strategy literature on tourism that focuses on strategic alliances and networks in this sector, defending the view that the network theory approach is particularly appropriate for the analysis of a complex industry like tourism.

We wish you all a good reading.

T. Diana L. van Aduard de Macedo-Soares Mariana de Queiroz Brunelli 